\title{
Influence of nutrients and light on autotrophic, mixotrophic and heterotrophic freshwater chrysophytes
}

\author{
Julia Rottberger ${ }^{1, *}$, Ansgar Gruber ${ }^{1}$, Jens Boenigk ${ }^{2}$, Peter G. Kroth ${ }^{1}$ \\ ${ }^{1}$ Plant Ecophysiology, Department of Biology, Universität Konstanz, 78457 Konstanz, Germany \\ ${ }^{2}$ Department of Botany, Universität Duisburg-Essen, 45117 Essen, Germany
}

\begin{abstract}
Chrysophyte algae show wide variation in their nutritional modes, which can be especially advantageous in oligotrophic conditions. However, the capacities and strategies of the algae to adapt to changing conditions may vary due to different nutritional requirements of individual species. In this context, comparative analyses evaluating the physiological range of mixotrophic chrysophytes are important to predict possible changes in phytoplankton composition. We compared 4 freshwater chrysophytes - Poteriospumella lacustris, Poterioochromonas malhamensis, Dinobryon divergens and Mallomonas annulata - under different growth conditions. The diatom Phaeodactylum tricornutum served as a photoautotrophic reference strain. We demonstrate active growth of $P$. lacustris and the mixotrophic $P$. malhamensis under chemoheterotrophic conditions. Neither of the chrysophytes were growing photoautotrophically; however, $P$. malhamensis showed some photosynthetic activity and survived longer when kept in the light. $M$. annulata, $P$. tricornutum and the mixotrophic $D$. divergens showed light-limited growth when kept in inorganic media. Even though $D$. divergens consumed living bacteria, it did not grow in the dark in the presence of the bacteria only. We detected large differences in the general nutritional preferences between the 2 mixotrophs in relation to the nutritional features of all investigated strains.
\end{abstract}

KEY WORDS: Mixotrophy $\cdot$ Oxygen evolution $\cdot$ Carbon $\cdot$ Culturing conditions $\cdot$ Phaeodactylum tricornutum

\section{INTRODUCTION}

Mixotrophic algae are able to meet their carbon demands by assimilating inorganic carbon $\left(\mathrm{CO}_{2}\right)$ as well as by taking up organic molecules. The uptake of organic substances is not limited to dissolved molecules (osmotrophy) but can also be accomplished by ingestion of detritus or living bacteria (phagotrophy). Chrysophytes (throughout the manuscript, this term refers to the chrysophytes sensu lato, comprising the classes Chrysophyceae and Synurophyceae [Andersen et al. 1999, Kristiansen \& Preisig 2007, Jordan \& Iwataki 2012]) are of special interest because their abundance may increase during phases of lake reoligotrophication (Gaedke 1998, Jeppesen et al. 2005) and because they often dominate mixotrophic phytoplankton populations (De Hoyos et al. 1998, Watson et al. 2001, Kamjunke et al. 2007). Chrysophytes are geographically widespread and abundant in freshwater and marine habitats as well as in soils (Sandgren 1988, Boenigk \& Arndt 2002, Massana 2011). While a large number of chrysophyte genera show mixotrophic traits (Porter 1988, Sanders \& Porter 1988), all the different metabolic lifestyles ranging from exclusively chemoheterotrophic to exclusively photoautotrophic nutrition can be found (Raven et al. 1995).

Several parameters may affect the growth competitiveness of mixotrophic chrysophytes. Besides carbon and phosphorous availability (Rothhaupt 1996a), light (de Castro et al. 2009), pH (Moser \& Weisse 
2011b) and temperature (Moser \& Weisse 2011a, Wilken et al. 2013) have also been shown to be important factors in laboratory studies. Furthermore, some chrysophytes require vitamin supply (Heinrich 1955). Mixotrophic chrysophytes are thought to be very competitive in oligotrophic waters because some of them may ingest bacteria, which are utilized as carbon and phosphorus source (Thingstad et al. 1996, Kamjunke et al. 2007, Unrein et al. 2007). Still, each of the mentioned parameters is likely to affect each chrysophyte species in a different way (Watson \& McCauley 2010, Moser \& Weisse 2011b), making it difficult to predict the success of certain mixotrophic species under changing conditions.

In the present study, we compare nutritionally different mixotrophic chrysophyte species to each other as well as to purely photoautotrophic or purely chemoheterotrophic reference species. We aimed to demonstrate how different chrysophytes are affected by nutritional parameters under identical conditions and by this to understand whether the observed differences may influence the competitive fitness of a single species. To this end, we tested different culturing conditions in order to find the most suitable conditions for physiological comparisons. Further, we specified which component of the culturing media limited maximum cell numbers of each protist to make sure that the macronutrients and not the trace metals or vitamins were the limiting factor. We performed comparative studies examining the influence of light and different carbon sources on all strains. Additionally, we compared photosynthetic capacities of all strains by conducting oxygen evolution measurements to complement results from the growth experiments.

\section{MATERIALS AND METHODS}

\section{Strains and standard culturing conditions}

The chrysophytes investigated in the present study were isolated from oligotrophic, alpine or pre-alpine freshwaters (Table 1) and include 2 mixotrophic strains, Dinobryon divergens FU18K_A (xenic) and Poterioochromonas malhamensis DS (axenic). The colourless heterotrophic Poteriospumella lacustris (strain JBM10) (axenic) and the photoautotrophic Mallomonas annulata WA 18K_M (xenic) were chosen as reference strains. As a photoautotrophic reference strain, we also studied the diatom Phaeodactylum tricornutum UTEX646.

Poteriospumella lacustris was cultured in modified inorganic basal medium (pH 7.2) (Hahn 2003) without
$\mathrm{NiCl}_{2}$ and with addition of dissolved organic matter (DOM) sources of $1 \mathrm{~g} \mathrm{l}^{-1}$ peptone (Roth), $1 \mathrm{~g} \mathrm{l}^{-1}$ yeast extract (Roth) and $1 \mathrm{~g} \mathrm{l}^{-1} \alpha$-D-glucose. Dinobryon divergens and Mallomonas annulata were grown in liquid WC medium ( $\mathrm{pH}$ 8) (Guillard \& Lorenzen 1972) with modified concentrations of TES buffer $\left(\mathrm{C}_{6} \mathrm{H}_{15} \mathrm{NO}_{6} \mathrm{~S} 500 \mu \mathrm{M}\right), \mathrm{NaHCO}_{3}(375 \mu \mathrm{M}), \mathrm{K}_{2} \mathrm{HPO}_{4}$ $(32 \mu \mathrm{M}), \mathrm{NaNO}_{3}(500 \mu \mathrm{M})$ and $\mathrm{MnCl}_{2}(0.09 \mu \mathrm{M})$. The standard medium for Poterioochromonas malhamensis was modified bacillariophycean medium (BM) (pH 7.2) (Schlösser 1994) with $236 \mu \mathrm{M} \mathrm{Na} \mathrm{CO}_{3}, 27 \mu \mathrm{M}$ iron(III) citrate hydrate, $214 \mu \mathrm{M}$ citric acid, $60 \mathrm{nM}$ $\mathrm{MnSO}_{4}, 200 \mu \mathrm{g} \mathrm{l}^{-1}$ thiamine-HCl, $10 \mu \mathrm{g} \mathrm{l} \mathrm{l}^{-1}$ biotin and DOM. Phaeodactylum tricornutum was grown in modified f/2 medium (pH 7) (Guillard \& Ryther 1962, Guillard 1975) with artificial half-concentrated sea salts (16.6 $\mathrm{g} \mathrm{l}^{-1}$ Tropic Marin ${ }^{\circledR}$, Dr. Biener) and $0.09 \mu \mathrm{M}$ manganese or on solid plates of modified $\mathrm{f} / 2$ (with $1.5 \%$ agar) for culture maintenance. The axenic state of the cultures was monitored regularly by light and fluorescence microscopy, using an automatic particle counter and by screening culture aliquots for growth of bacterial colonies on solid media (1.5\% agar) containing DOM. A consortium of several bacterial strains served as prey during feeding experiments. The bacteria were isolated from Dinobryon divergens cultures by plating a culture sample on WC medium including DOM and incubating the plate for $1 \mathrm{wk}$ at room temperature. The bacterial consortium was transferred to fresh plates monthly without further purification. The bacteria were grown in liquid WC medium with DOM for feeding experiments.

Cultures were generally grown at $20^{\circ} \mathrm{C}$ in Erlenmeyer flasks without shaking under sterile conditions and at a light intensity of 30 to $40 \mu \mathrm{mol}$ photons $\mathrm{m}^{-2} \mathrm{~s}^{-1}$ on the surface of the culture flasks. If not noted otherwise, the light:dark cycle was $16 \mathrm{~h}: 8 \mathrm{~h}$.

\section{Cell counts of protists}

Cell counts and the determination of the biovolume of protists were performed with an automatic particle counter according to the Coulter principle ('Coulter counter', Multisizer III, Beckman Coulter) using a capillary with an aperture of $100 \mu \mathrm{m}$ diameter. Directly prior to measurements, 100 to $900 \mu \mathrm{l}$ of a cell suspension were diluted in $12 \mathrm{ml}$ of the electrolyte IsotonII-Diluent (Beckman Coulter) by pipetting. Measurements were performed in triplicates for each sample and averaged. To reduce background signals from dust, precipitates and fibers, a sample of the sterile control was analyzed and subtracted. To gain 
Table 1. Algal strains investigated in the present study

\begin{tabular}{|c|c|c|c|c|c|}
\hline Algal strain and origin & Axenic? & $\begin{array}{l}\text { Reference for } \\
\text { strain description }\end{array}$ & $\begin{array}{l}\text { Carbon } \\
\text { acquisition }\end{array}$ & Habitus & $\begin{array}{l}\text { References for } \\
\text { phagotrophy }\end{array}$ \\
\hline \multicolumn{6}{|l|}{ Mallomonas annulata WA 18K_M } \\
\hline Lake Wallersee, Austria & No & J. Boenigk (unpubl.) & Autotroph & Unicellular & None \\
\hline \multicolumn{6}{|l|}{ Dinobryon divergens FU 18K-A } \\
\hline Lake Fuschelsee, Austria & No & J. Boenigk (unpubl.) & Mixotroph & Colonial & $\begin{array}{l}\text { Jones \& Rees (1994), } \\
\text { Veen (1991) }\end{array}$ \\
\hline \multicolumn{6}{|c|}{ Poterioochromonas malhamensis DS } \\
\hline Lake Constance, Germany & Yes & Hahn \& Höfle (1998) & Mixotroph & $\begin{array}{l}\text { Unicellular, } \\
\text { stalks }\end{array}$ & Hahn \& Höfle (1998) \\
\hline \multicolumn{5}{|l|}{ Poteriospumella lacustris JBM10 } & Boenigk et al. (2006) \\
\hline \multicolumn{6}{|c|}{ Phaeodactylum tricornutum Bohlin UTEX 646} \\
\hline Baltic Sea, Finland & No & $\begin{array}{l}\text { Droop (1954), } \\
\text { De Martino et al. (2007) }\end{array}$ & Autotroph & Unicellular & None \\
\hline
\end{tabular}

the cell density (i.e. cell number per milliliter), the curve area corresponding to the algal cells was calculated. The curve area limits were 3 to $20 \mu \mathrm{m}$ for Poteriospumella lacustris, Phaeodactylum tricornutum and Poterioochromonas malhamensis, 3.5 to $20 \mu \mathrm{m}$ for Dinobryon divergens and 4 to $20 \mu \mathrm{m}$ for Mallomonas annulata. Cell volume and cell diameters were both extracted from the same size distribution graphs after measurements with the Multisizer III by choosing 'diameter' or 'volume' as the $x$-axis.

Except for Dinobryon divergens, dead cells or cell fragments were clearly distinguishable from living cells by size. To obtain a better evaluation of the number of living cells of $D$. divergens, we subtracted $30 \%$ of the cell counts representing empty loricas during exponential phases in those cases where numbers of living cells were required, but this subtraction was not used for the determination of growth rates (for details, see Rottberger et al. 2013).

\section{Cell counts of bacteria}

Bacterial cell counting was conducted with unstained cells using a phase contrast microscope and a micrometer ocular at $640 \times$ total magnification. Cell counts of each sample were performed in quadruples and averaged. The concentration of bacteria added during feeding experiments was adjusted to calculated optical densities (ODs) of 0.01 and 0.005. This was achieved by measuring the OD at $\lambda=600 \mathrm{~nm}$ of bacterial stock solutions with an $\mathrm{OD}_{600}$ between 0.1 and 0.5 using a spectrophotometer and by calculating the necessary volume of stock suspension to achieve final ODs of 0.01 and 0.005 in the culturing flask. The OD measurements were exemplarily cor- related to microscopic cell counts of living bacteria grown in WC medium with DOM by a dilution series ranging from $\mathrm{OD} 0$ to 0.5 . Bacterial cell numbers were then calculated by the formula of the linear regression curve over all data points (Fig. S1 in the Supplement at www.int-res.com/articles/suppl/a071 p179_supp.pdf).

Accompanying bacteria in the cultures of Dinobryon divergens and Mallomonas annulata were counted exemplarily using phase contrast microscopy in mid-exponential phase at a density of 47000 cells $\mathrm{ml}^{-1}$ of Dinobryon divergens and 73000 cells $\mathrm{ml}^{-1}$ of Mallomonas annulata. Cultures of D. divergens and $M$. annulata were grown under standard conditions in triplicates with an initial inoculum of 1000 algal cells $\mathrm{ml}^{-1}$. Each triplicate was sampled, 4 bacterial counts per sample were conducted, and all 12 counts per alga were averaged.

\section{Growth experiments}

Growth experiments were performed in triplicates. Protist cultures were inoculated with a start abundance of 1000 to 10000 cells ml ${ }^{-1}$. Cultures were grown in the light (16 h light:8 h dark) up to a cell density of approximately 50000 to 100000 cells ml $^{-1}$ during light-limitation experiments prior to exposing them to a $4 \mathrm{~h}$ light:20 h dark $(6 \mathrm{~h}$ light:20 $\mathrm{h}$ dark for Mallomonas annulata) or $8 \mathrm{~h}$ light:16 h dark cycle. For experiments in complete darkness, culture flasks were wrapped with aluminium foil directly after inoculation.

In aerated treatments, dry, double sterile-filtered air (0.2 $\mu \mathrm{m}$ PTFE-filters, Whatman) was bubbled into the culture flasks through silicon plugs. In agitated 
treatments, culture flasks were placed on a horizontal shaker (GFL 3020, $100 \mathrm{rpm}$ ).

To test photoautotrophic growth, all protists were grown under standard conditions and in their standard medium (see 'Strains and standard culturing conditions' above), except that DOM was omitted in the culturing media of Poteriospumella lacustris and Poterioochromonas malhamensis. DOM was not added to the culturing media of $P$. lacustris or $P$. malhamensis during feeding experiments. Feeding experiments were performed with either autoclaved or living bacteria that had been washed twice with $0.9 \%$ sodium chloride. Autoclaved bacteria were added to the culturing media of all protists to a calculated bacterial $\mathrm{OD}_{600}$ of 0.01 in the culture (see previous section). In a separate experiment, living bacteria were added to the culturing medium of Dinobryon divergens, to a calculated bacterial $\mathrm{OD}_{600}$ of 0.005 . Bacteria were added to each culture flask prior to inoculation with the protists. Growth of the protists was analysed by automatic particle counting.

Fluorescence labelling of bacteria was used as a tool to visualize the ingestion of undamaged bacteria (Sherr et al. 1987, Chrzanowski \& Simek 1990) and was accordingly applied to confirm active ingestion of non-autoclaved bacteria by Dinobryon divergens. A stock solution of fluorescently labelled living bacteria was generated by staining cells with SYTO ${ }^{\circledR 9}$ Green fluorescent nucleic acid stain (Invitrogen) in a small volume of medium $(100 \mu \mathrm{l})$ for $1 \mathrm{~h}$. After that the solution was washed to remove surplus dye. From the washed stock solution, fluorescently labelled bacteria were added to $D$. divergens cultures in exponential growth phase with an $\mathrm{OD}_{600}=0.005$. The volume of stained bacteria needed to achieve this OD was determined by measuring the OD of a parallel, non-stained bacterial culture that was treated identically, except that medium was used instead of staining solution. Ingestion of bacteria was analysed after 2 to $6 \mathrm{~h}$ using a fluorescence microscope to gain an overview and a confocal laser scanning microscope for more detailed studies of single protist cells.

\section{Maximum yield limitation experiments}

Potential limitations on the maximum cell numbers of each investigated strain were tested under standard conditions by increasing the concentration of DOM, glucose, the nitrate source, the phosphate source, the vitamin solution or the trace metal solution during stationary phase to 3 -fold the standard concentrations.

\section{Oxygen measurements}

Cells were harvested during late exponential growth phase by gentle centrifugation $(<1500 \times g)$. Cell densities were adjusted to $>10^{6}$ cells $\mathrm{ml}^{-1}$ using a 1:1 mixture of culture supernatant and fresh culturing medium. Oxygen measurements were performed at $20^{\circ} \mathrm{C}$ with $1 \mathrm{ml}$ of the cell suspensions in a Clarktype electrode (Hansatech). Samples were acclimatized to the respective light intensity ( 0 to $1000 \mu \mathrm{mol}$ photons $\mathrm{m}^{-2} \mathrm{~s}^{-1}$ ) within the electrode chamber for $10 \mathrm{~min}$ without stirring. Measurements were then performed within 4 min of continuous illumination and gentle stirring (30 rpm). The biovolume of the cells in the samples was determined after oxygen measurements using the Coulter counter, and rates were then calculated to fmol $\mathrm{O}_{2} \mu^{-3} \mathrm{~h}^{-1}$. All oxygen evolution rates were determined from triplicates measured within 3 successive days.

\section{Statistics}

The significance of differences was calculated by a Student's $t$-test using SigmaPlot 12.0 (Systat Software). Here, normality distribution was tested by a Shapiro-Wilks test with a confidence interval of $95 \%$, a score of 0.05 and a p-value to reject normality of 0.05 .

\section{RESULTS AND DISCUSSION}

\section{Selection and characterization of strains}

For comparative physiological studies under laboratory conditions, we chose 2 mixotrophic freshwater species of the genera Poterioochromonas and Dinobryon that are both well-described in the literature (e.g. Bird \& Kalff 1987, Caron et al. 1990, Boenigk et al. 2006, Watson \& McCauley 2010) and compared them to one photoautotrophic (Mallomonas annulata) and one heterotrophic chrysophyte (Poteriospumella lacustris). In order to compare the results to a physiologically and genetically well-investigated unicellular organism that also belongs to the stramenopiles, we studied the brackish-water diatom Phaeodactylum tricornutum.

Bacteria were not detected in standard cultures of Phaeodactylum tricornutum but occasionally appeared when the cells were grown in media containing DOM. Dinobryon divergens and Mallomonas annulata were uni-algal but not bacteria-free in all 
media utilized for the experiments. Cultivation of bacteria-free Dinobryon sertularia has already been described (Lehman 1976); however, our attempts to purify $D$. divergens via dilution, by a single-cell pipetting approach or by incubation with different antibiotics (mainly of the $\beta$-lactame group) were unsuccessful. It has been suggested that for D. cylindricum, the presence of bacteria or organic compounds might be obligatory due to certain unknown growth factors (Caron et al. 1993).

\section{Optimization of culture conditions}

Cultures of different chrysophytes have successfully been maintained in batch cultures without agitation (Caron et al. 1993), with occasional agitation (Rothhaupt 1996b), with continuous agitation (Van Donk et al. 2009), with air-bubbling (Maberly et al. 2009 ) or with supply of $4 \% \mathrm{CO}_{2}$ (Myers \& Graham 1956). In the present study, we tested the conditions of no agitation, shaking and aeration (Fig. 1). Shaking resulted in slower growth of Mallomonas annulata, Dinobryon divergens and Poterioochromonas malhamensis (growth rates were reduced by 55.8, 32.2 and $54.2 \%$, respectively) than without agitation, while Poteriospumella lacustris and Phaeodactylum tricornutum performed equally at all conditions. As the $\mathrm{CO}_{2}$ supply might be limiting in non-agitated culture flasks, we grew aerated cultures in parallel and found higher growth rates for $D$. divergens (means \pm SD: $\mu=0.39 \pm 0.01 \mathrm{~d}^{-1}$ compared to $\mu=0.23$ $\pm 0.01 \mathrm{~d}^{-1}$ in the agitated treatment), while the growth of $M$. annulata was lower $\left(\mu=0.50 \pm 0.02 \mathrm{~d}^{-1}\right.$ compared to $\mu=0.57 \pm 0.01 \mathrm{~d}^{-1}$ ) (Fig. 1). Growth rates of $P$. tricornutum were nearly identical $(\mu=1.03 \pm$ $0.05 \mathrm{~d}^{-1}$ compared to $\mu=1.04 \pm 0.03 \mathrm{~d}^{-1}$ ). Aeration enhanced growth of $M$. annulata and $P$. tricornutum in terms of maximum cell densities (by 29.2 and $59.1 \%$, respectively). In contrast to $P$. tricornutum (Johnston \& Raven 1996, Matsuda et al. 2011), chrysophytes including Mallomonas species apparently lack effective carbon-concentrating mechanisms (CCM) (Maberly et al. 2009, Bhatti \& Colman 2011). Consequently, the investigated chrysophytes may be more affected by the slow diffusive $\mathrm{CO}_{2}$ supply in nonagitated cultures than $P$. tricornutum. As demonstrated earlier (Herth \& Zugenmaier 1979, Veen 1991), Dinobryon divergens is very sensitive to changes in the experimental set-up (e.g. sensitive to mechanical stimuli or to changes in light regime or temperature). Accordingly, under aerated conditions, we found colony fragmentation, which increased the number of unicellular individuals (Fig. S2 in the Supplement). However, we did not observe any impact on cellular motility and shape of the loricas under aeration, while the growth rates of $D$. divergens were increased. Taken together, culturing all strains without agitation was the most convenient unified condition for comparison.
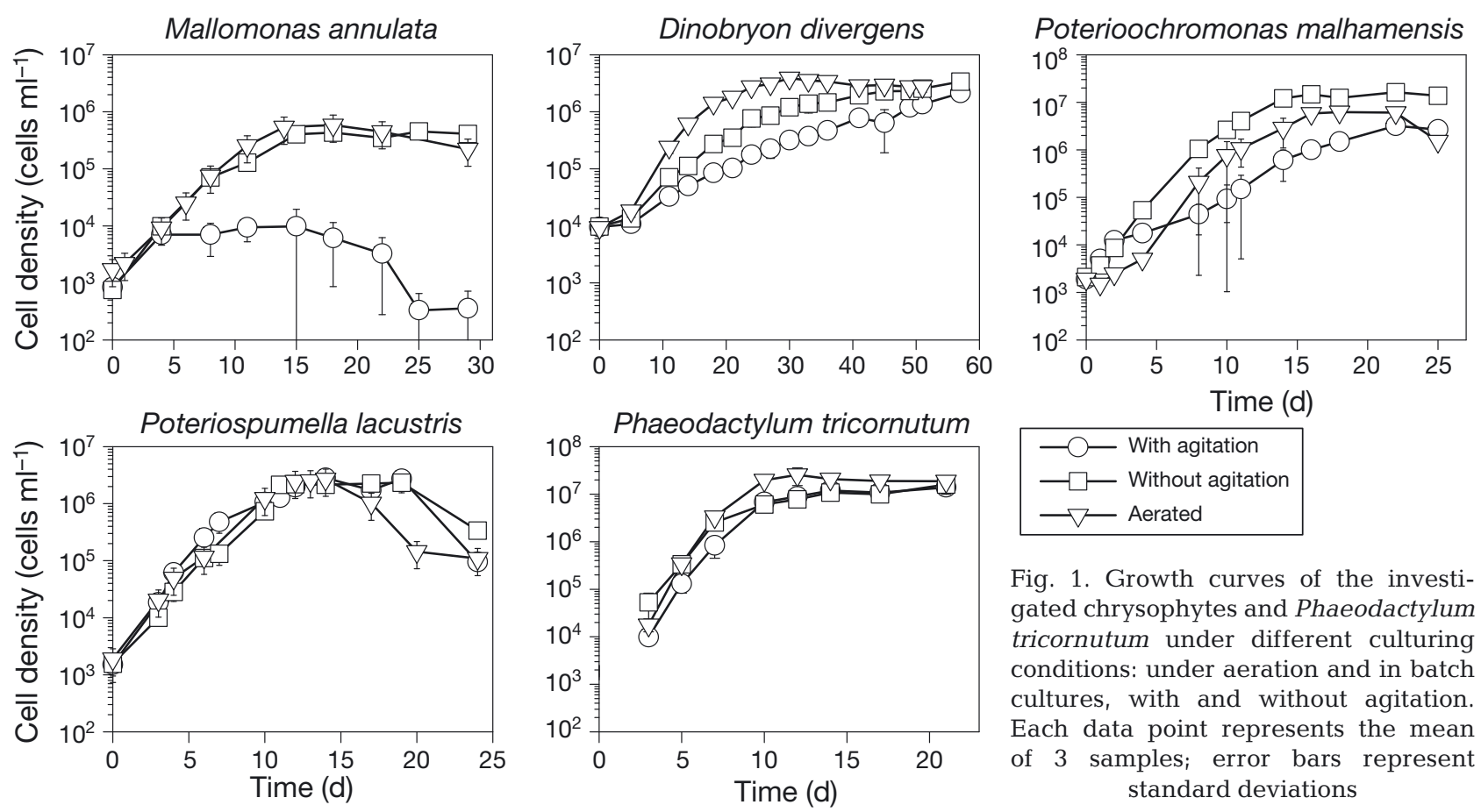

Fig. 1. Growth curves of the investigated chrysophytes and Phaeodactylum tricornutum under different culturing conditions: under aeration and in batch cultures, with and without agitation. Each data point represents the mean of 3 samples; error bars represent standard deviations 


\section{Influence of bacteria}

Under photoautotrophic conditions, sustained growth of Phaeodactylum tricornutum, Dinobryon divergens and Mallomonas annulata was observed, while Poterioochromonas malhamensis and Poteriospumella lacustris failed to grow (Fig. 2; light, no bacteria).

Feeding with autoclaved bacteria increased the growth of Poterioochromonas malhamensis and Poteriospumella lacustris but not that of Dinobryon divergens and Phaeodactylum tricornutum (t-test, $\mathrm{p}=0.635$ and $\mathrm{p}=0.387$ ) (Fig. 2). Mallomonas annulata even showed slower growth rates in the presence of autoclaved bacteria (means \pm SD: $\mu=0.57 \pm 0.01$ reduced to $\mu=0.11 \pm 0.06$ when autoclaved bacteria were added). Obviously, the autoclaved bacteria were not exploited as a major source of energy and carbon in the light or dark by $M$. annulata, $P$. tricornutum or $D$. divergens. However, addition of living bacteria to cultures of $D$. divergens resulted in a slight and significant $(t$-test, $\mathrm{p}=$ $0.001)$ increase of growth rates $\left(\mu=0.29 \pm 0.01 \mathrm{~d}^{-1}\right)$ compared to non-supplied cultures $\left(\mu=0.25 \pm 0.01 \mathrm{~d}^{-1}\right)$ (Fig. S3 in the Supplement). Fluorescently labelled living bacteria were clearly visible inside of Dinobryon cells, demonstrating ingestion of bacteria by the alga (Fig. 3, Fig. S4 in the Supplement).

In accordance with other studies on Dinobryon spp. (Caron et al. 1993, Kamjunke et al. 2007), the increase of growth rates obtained by additional
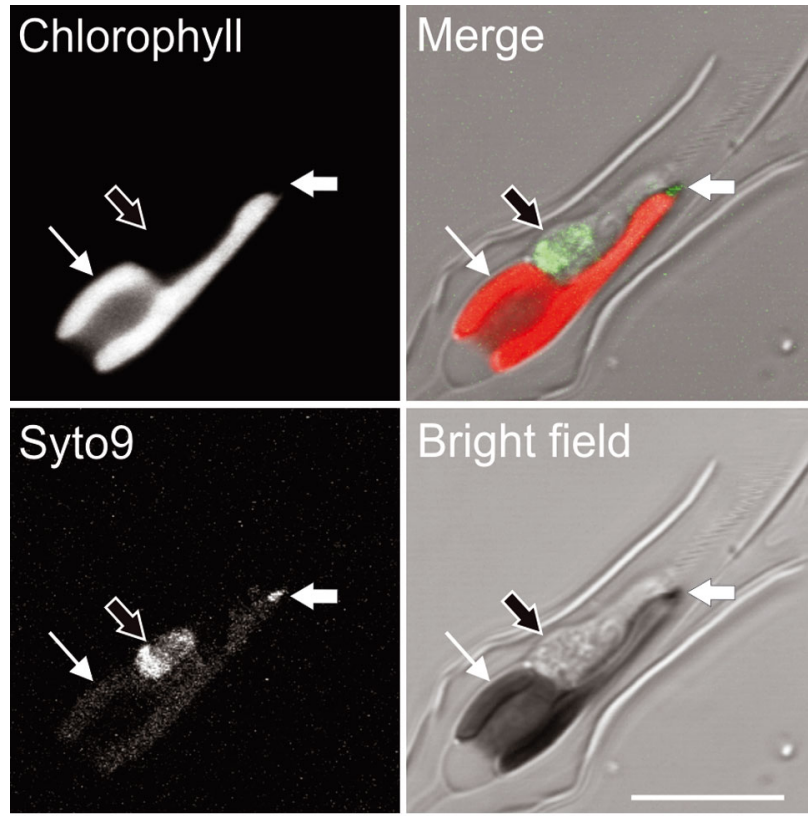

Fig. 3. Micrographs of Dinobryon divergens fed with living fluorescently labelled bacteria. Bacteria were labelled with a fluorescent dye (Syto ${ }^{\circledR 9}$ ). Ingested bacteria were visible by green fluorescence inside of the algal cell (black arrow). Additionally, the eyespot of $D$. divergens showed green autofluorescence (thick white arrow), while the plastid showed red autofluorescence (thin white arrow). A slight background fluorescence of the chloroplast was visible in the green fluorescence channel (Syto ${ }^{\circledR 9}$; see Fig. S4 in the Supplement for additional controls). Scale bar $=10 \mu \mathrm{m}$, applies to all micrographs
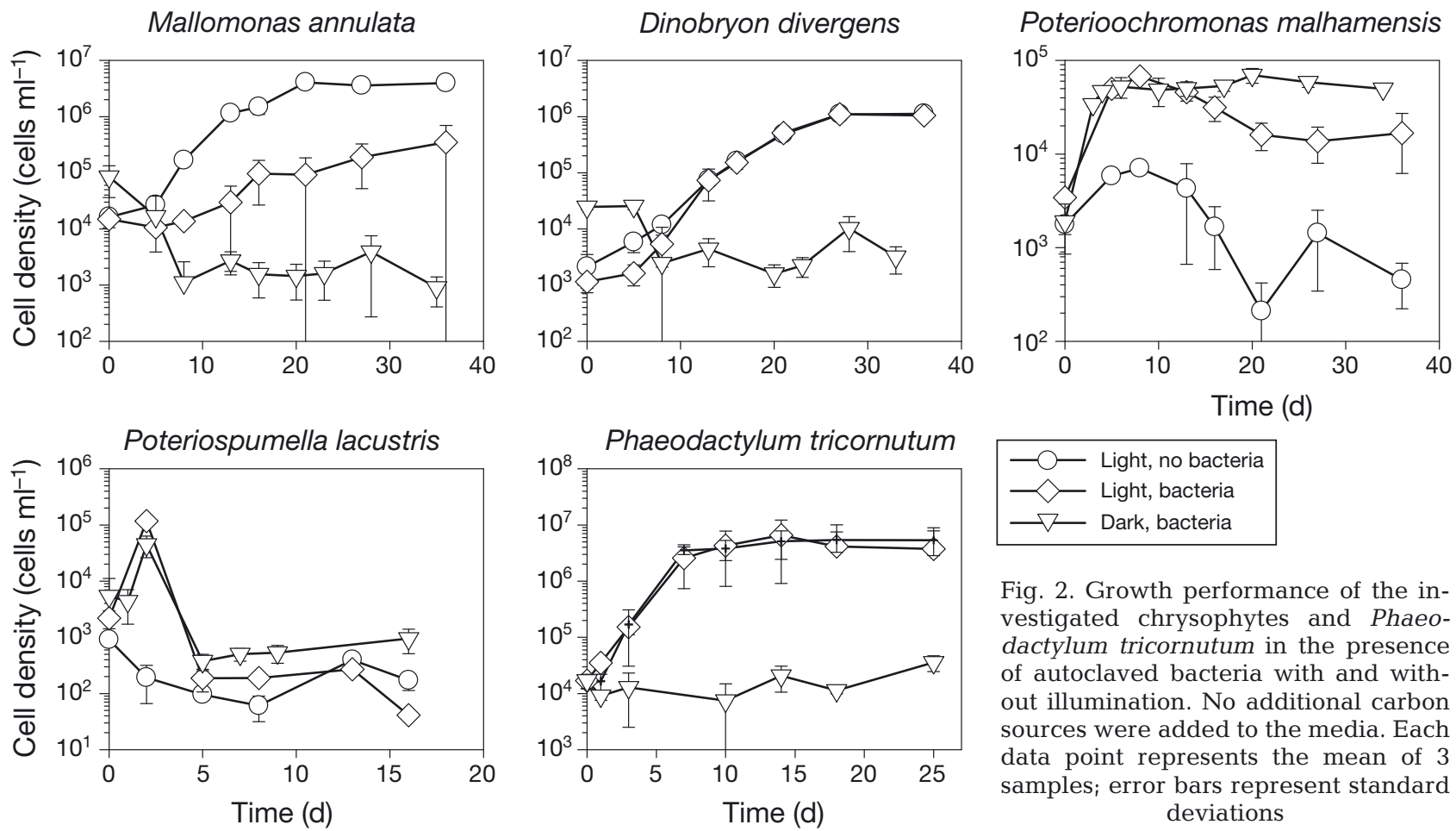

Fig. 2. Growth performance of the investigated chrysophytes and Phaeodactylum tricornutum in the presence of autoclaved bacteria with and without illumination. No additional carbon sources were added to the media. Each data point represents the mean of 3 samples; error bars represent standard deviations 
supply with living bacteria was lower than the increase obtained by additional $\mathrm{CO}_{2}$ supply via aeration, which indicates a stronger limitation by photosynthesis than by organic nutrient sources under the conditions applied. The outcome of feeding experiments with autoclaved bacteria may have been affected by the accompanying bacteria (see 'Selection and characterization of strains' above) in cultures of Dinobryon divergens and Mallomonas annulata. Bacterial densities under standard conditions were $10^{7}$ cells $\mathrm{ml}^{-1}$ in cultures of $M$. annulata and $5 \times 10^{6}$ cells $\mathrm{ml}^{-1}$ in cultures of D. divergens in mid-exponential phase. Due to feeding on dead algal material, more bacteria were present in later growth phases. Less than $1 \mathrm{ml}$ of exponentially growing algal cultures per $50 \mathrm{ml}$ was used for inoculation. Thus, at the beginning of growth experiments, the maximum bacterial densities were $1 \times 10^{5}$ cells ml $\mathrm{m}^{-1}$ in cultures of D. divergens and $2 \times 10^{5}$ cells $\mathrm{ml}^{-1}$ in cultures of M. annulata. For the feeding experiments, $3 \times 10^{6}$ cells of autoclaved bacteria were added; hence, there were $\sim 15$-fold more dead than living bacteria present at the beginning. The dead bacteria provided a source of dissolving organic material for the accompanying bacteria, which probably grew much faster in these experiments than after the addition of living bacteria or no bacteria. The growing bacteria perhaps depleted some limiting resources quickly (e.g. nitrate), so that $M$. annulata grew slower in experiments with autoclaved bacteria (Fig. 2). Apparently D. divergens could not profit from the increase in living bacteria because ingestion rates were already maximal at standard conditions. However, the cause for an increase of growth rates of Dinobryon divergens in feeding experiments with living bacteria remains unclear. A possible explanation would be that a portion of the bacteria might not have been accessible for D. divergens simply because bacterial cell agglomerates were too large to be taken up (Fig. S5 in the Supplement). Using different fluorescent beads, size selection was observed for Dinobryon spp. in field studies (Bird \& Kalff 1987) and in laboratory experiments (Veen 1991). However, Poterioochromonas malhamensis and Poteriospumella lacustris apparently were able to exploit the cell agglomerates in our study because both showed growth in the presence of the autoclaved bacteria (Fig. 2). Accordingly, P. malhamensis cells have been found to graze on organisms 2- to 3-fold larger than their own cell diameter (Zhang \& Watanabe 2001).

\section{Nutritional limitations in the stationary phase}

To identify further limiting factors for the maximum cell yield, we examined the role of macronutrients (organic C, N and P) or supplements (vitamins and trace metals) (Fig. 4). Nitrate was the most limiting nutrient for the photoautotrophic Mallomonas annulata as cell densities increased by $68 \%$ after addition of $1 \mathrm{mM}$ nitrate during the stationary phase. Nitrate and phosphate concentrations may also influence the growth response of Mallomonas species in natural habitats (Scott et al. 2009) and under laboratory conditions (Kim et al. 2009, Lee et al. 2012). Kim et al. (2009) showed that different Mallomonas caudata strains had different growth rates at identical nitrate concentrations, suggesting that nitrate turnover might be a key element of growth response in Mallomonas spp. Maximum cell densities of $M$. caudata varied around $10^{4}$ cells $\mathrm{ml}^{-1}$ (Kim et al. 2009), whereas we observed up to $5 \times 10^{5}$ cells $\mathrm{ml}^{-1}$ for $M$. annulata, indicating that enhanced biomass generation in unialgal laboratory cultures of Mallomonas spp. may be accomplished by excessive addition of nitrate to the respective media. However, this hypothesis requires further investigation since the bacteria in cultures of $M$. caudata and $M$. annulata are additional nitrate consumers, which introduce a possible source of variation in bacterial cell density and nitrate demand between the cultures.

The growth of the heterotrophic Poteriospumella lacustris and the mixotrophic Poterioochromonas malhamensis was limited by the organic matter (peptone, yeast extract and glucose) (Fig. 4). As peptone and yeast extract are an undefined mixture of organic compounds, this finding alone is difficult to interpret. However, we could show that organic carbon is one of the limiting compounds in the dissolved organic matter by adding exclusively glucose to stationary phase cultures, which led to a 2.5-fold increase in maximum cell densities of $P$. malhamensis. Cell densities of $P$. lacustris were stable after the addition of glucose, while cell densities decreased rapidly in the control culture without added glucose.

None of the separately tested components (nitrate, phosphate, vitamin solution or trace metal solution) caused a positive growth response in the stationary phase of Dinobryon divergens and Phaeodactylum tricornutum cultures. Nonetheless, it is possible that $P$. tricornutum as well as $D$. divergens were limited by a combination of several elements (e.g. $\mathrm{PO}_{4}{ }^{3-}$ and $\mathrm{NO}^{3-}$ ) or by other factors not tested (e.g. optimal Ca:Mg ratios; Lehman 1976). In fact, a combined depletion of phosphate and nitrate has recently been 

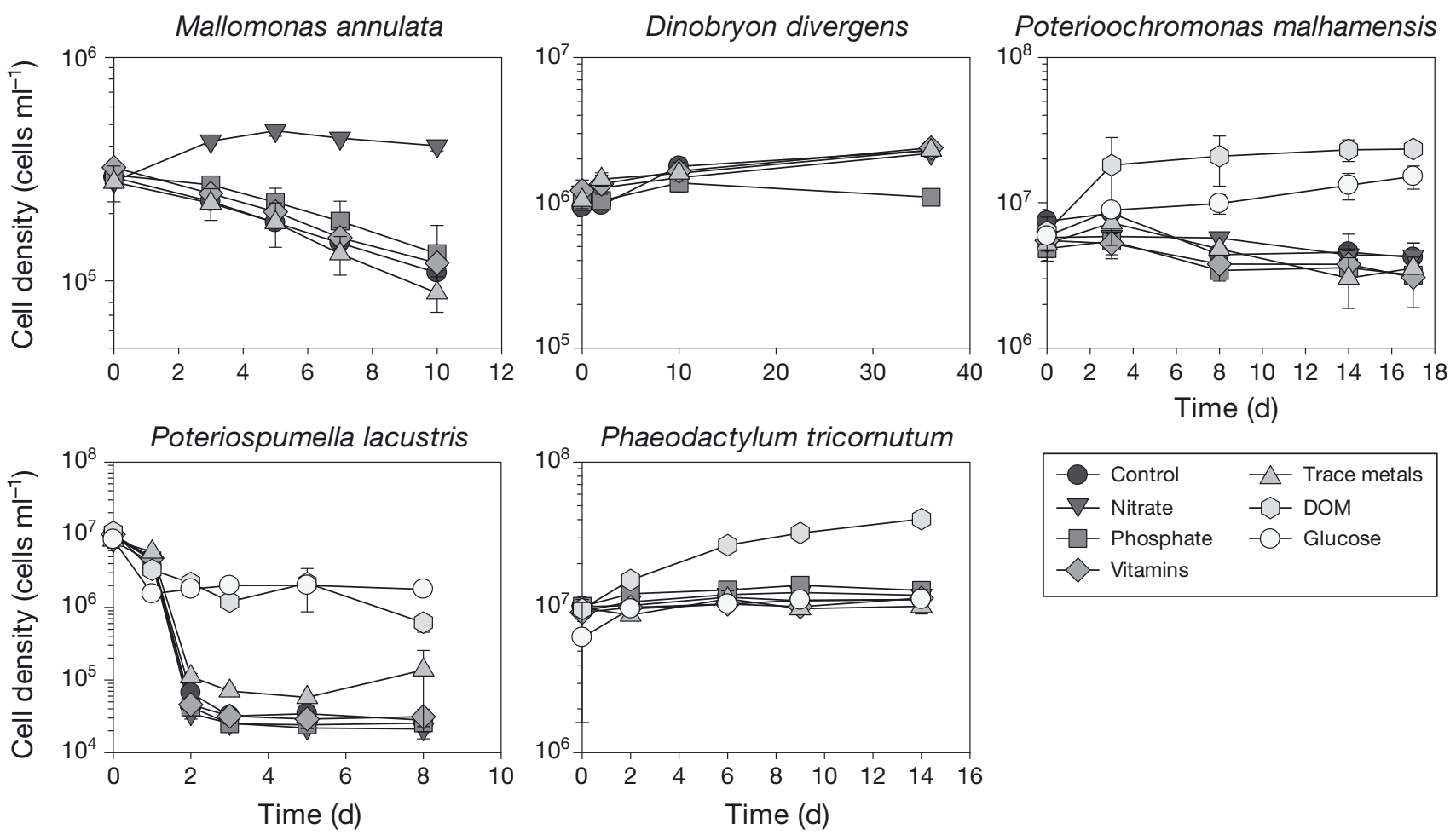

Fig. 4. Response of the investigated chrysophytes and Phaeodactylum tricornutum to the addition of nutrients in the stationary phase. Growth curves of protists after addition of $2 \times$ concentrated (for individual concentrations, see 'Strains and standard culturing conditions') nitrate source, phosphate source, vitamin solution, trace metal solution, glucose or DOM in stationary phase (time point 0). The control, also in stationary phase, was supplemented with $1 \mathrm{ml}$ of sterile double-distilled water. Each data point represents the mean of 3 samples; error bars represent standard deviations

shown at the onset of the stationary phase for P. tricornutum grown in aerated bioreactors with similar growth rates $(\mu=1.05$, deduced from cell densities shown in Fig. 1 by Valenzuela et al. 2012) compared to our aeration experiments $(\mu=1.04 \pm 0.03$; our Fig. 1). Addition of potassium phosphate to $D$. divergens resulted in a slight decline of particle numbers (Fig. 4) and a strong decline of vital cells according to a microscopic survey (Fig. S6 in the Supplement). Potassium toxicity would explain the death of the alga but is discussed controversially in the literature (Lehman 1976, van Donk et al. 1988).

\section{Influence of dissolved organic matter}

In contrast to experiments under photoautotrophic conditions, Poteriospumella lacustris and Poterioochromonas malhamensis grew well osmotrophically when DOM was supplied reaching maximum cell densities of $>5 \times 10^{6} \mathrm{cells} \mathrm{ml}^{-1}$. In the stationary phase, axenic growth was limited by peptone, glucose and yeast extract (DOM) (Fig. 4). Different $P$. malhamensis isolates have been shown to assimilate the bulk of their required carbon via phagotrophy or osmotrophy and only to a minor extent by photoautotrophy (Pringsheim 1952, Hutner et al. 1953, Caron et al. 1990, Sanders et al. 1990, Hahn \& Höfle 1998, Zhang \& Watanabe 2001, Boenigk et al. 2006). Our experiments support these results; however, DOM may contain additional nutrients that support osmotrophic growth; therefore, we tested glucose and glycerol as defined organic carbon sources. Osmotrophic dissimilation of glucose by $P$. malhamensis has been demonstrated within 1 to $2 \mathrm{~d}$ after transfer to an inorganic medium (Reazin 1956). In our experiments, only poor growth was observed with glucose $\left(\mu=0.12 \pm 0.05 \mathrm{~d}^{-1}\right)$ or glycerol $(\mu=0.09 \pm$ $0.02 \mathrm{~d}^{-1}$ ) as a carbon source under axenic conditions (Fig. S7 in the Supplement) compared to growth with DOM $\left(\mu=0.78 \pm 0.03 \mathrm{~d}^{-1}\right)$ (Fig. 1, without agitation). However, the additional supply of glucose under nutrient limitation increased cell densities of $P$. malhamensis substantially and quickly (Fig. 4). This indicates the presence of additional growth-limiting substances, which might be present either in the yeast extract or the peptone of the DOM and which might be necessary for sustained osmotrophic growth of $P$. 
malhamensis with glucose. For instance, citric acid cycle intermediates have been proposed to act in this way for P. malhamensis (Hutner et al. 1953). We can exclude soil extract in the standard BM medium as a source for growth-limiting substances as its omission did not affect growth rates or maximum cell densities of $P$. malhamensis during axenic cultivation.

The addition of peptone, glucose and yeast extract to cultures of Mallomonas annulata and Dinobryon divergens resulted in intense growth of the bacteria, making the determination of algal growth rates difficult. Thus, for these algae, we only tested particulate organic carbon sources. A summary for all 5 protists concerning the growth with different carbon sources is given in Table 2.

\section{Influence of light}

The role of light for growth of the protists was investigated by incubating the cells at different light:dark cycles and by measuring oxygen evolution using a Clark electrode (Table 2). Although oxygen evolution is often normalized to the chlorophyll content of the cells, we chose biovolume $\left(\mu \mathrm{m}^{3}\right)$ for normalization because a nonphotosynthetic organism was included here. Maximum oxygen evolution rates of Phaeodactylum

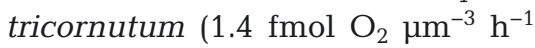

or $80 \mathrm{fmol} \mathrm{O}_{2} \mathrm{cell}^{-1} \mathrm{~h}^{-1}$; at $\mathrm{pH} 7$ to $8,20^{\circ} \mathrm{C}, 200 \mu \mathrm{mol}$ photons $\mathrm{m}^{-2} \mathrm{~s}^{-1}$ ) were similar to those obtained in other studies $\left(\sim 40 \mathrm{fmol} \mathrm{O}_{2}\right.$ cell $^{-1} \mathrm{~h}^{-1}$ [Patel \& Merrett 1986], 20 to $100 \mathrm{fmol} \mathrm{O}_{2}$ cell $^{-1} \mathrm{~h}^{-1}$ [Müller \& Wilhelm 1997]). All the photosynthetic algae in our study reached maximum oxygen evolution rates at light intensities between 150 and $200 \mu \mathrm{mol}$ photons $\mathrm{m}^{-2} \mathrm{~s}^{-1}$ (Fig. 5).

As expected, Mallomonas annulata showed photoautotrophic performance with maximum oxygen evolution rates of $1.48 \pm 0.31 \mathrm{fmol} \mathrm{O}_{2} \mu \mathrm{m}^{3} \mathrm{~h}^{-1}$, which

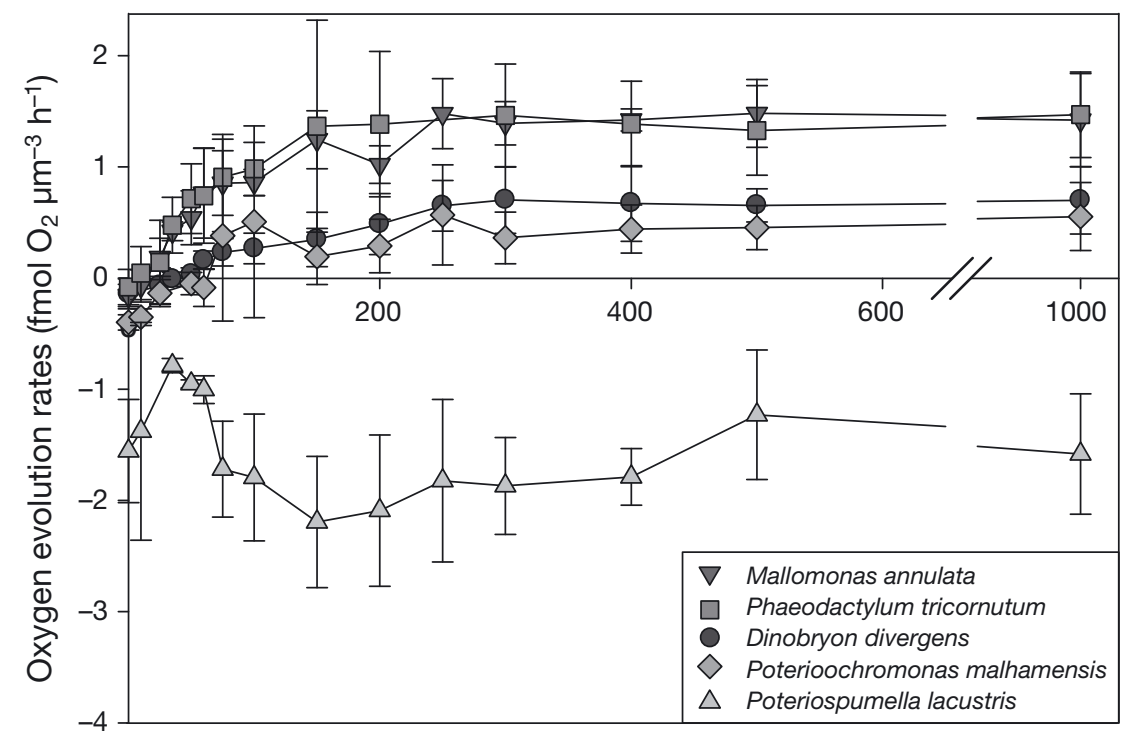

Light intensity ( $\mu \mathrm{mol}$ photons $\mathrm{m}^{-2} \mathrm{~s}^{-1}$ )

Fig. 5. Light-dependent oxygen evolution rates in late exponential growth phase (above zero: $\mathrm{O}_{2}$ production, below zero: $\mathrm{O}_{2}$ consumption) for the investigated chrysophytes and Phaeodactylum tricornutum standardized per biovolume and measured at different light intensities. Each data point represents the mean of 3 samples; error bars represent standard deviations

Table 2. Summary of the growth experiments. DOM: dissolved organic matter

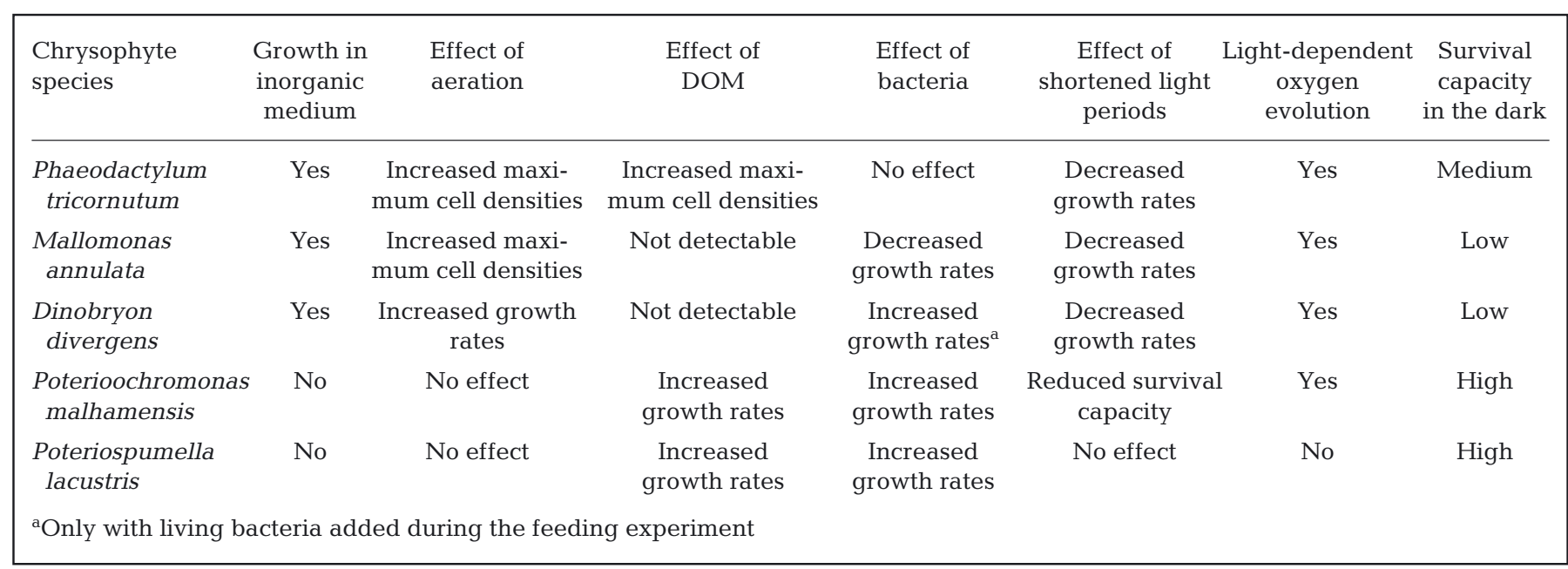


is as high as the maximum oxygen evolution rates of Phaeodactylum tricornutum $\left(1.46 \pm 0.46 \mathrm{fmol} \mathrm{O}_{2} \mu \mathrm{m}^{-3}\right.$ $\mathrm{h}^{-1}$ ) (Fig. 5). Shortening of the photoperiod resulted in lower growth rates of both algae (Fig. 6). When cultures were shifted to shorter light periods, cell densities of $M$. annulata (6 h light) decreased by $32.3 \%$, while $P$. tricornutum still showed positive growth rates at $4 \mathrm{~h}$ light. Thus, $P$. tricornutum is apparently better at coping with light limitation than M. annulata (see also Kamp et al. 2011, Rottberger et al. 2013).

While light is obviously indispensable for Mallomonas annulata, heterotrophic growth rates as well as maximum cell densities of Poteriospumella lacustris were similar in the light $(\mu=0.63 \pm 0.04)$ and in the dark $(\mu=0.64 \pm 0.04)$ (Fig. 6). Also, shortened photoperiods had no negative effects on growth in the presence of DOM. Oxygen evolution rates always remained negative due to respiration $\left(-1.5 \mathrm{fmol} \mathrm{O}_{2}\right.$ $\mu \mathrm{m}^{-3} \mathrm{~h}^{-1}$ ), independent of light (Fig. 5).
The mixotrophic Poterioochromonas malhamensis is able to grow heterotrophically in the dark and in the light. Holen (1999) showed that, different from other culture strains, the ingestion rates of bacteria by a freshly isolated $P$. malhamensis strain were affected by the light intensities applied. We did not observe differences between the growth rates of $P$. malhamensis in complete darkness and under the low-light conditions applied (Fig. 6). However, we found that the rate of photosynthetic oxygen evolution in $P$. malhamensis depends on light intensity (Fig. 5). Possibly the applied light intensity of 30 to $45 \mu \mathrm{mol}$ quantum $\mathrm{m}^{-2} \mathrm{~s}^{-1}$ was too low to affect growth rates, and experiments under high-light conditions would have revealed a relationship between light intensity and growth rates.

Prolonged cell maintenance in the stationary phase is only possible if the metabolism can switch to other metabolic pathways that are not dependent on a limited resource or if enough storage
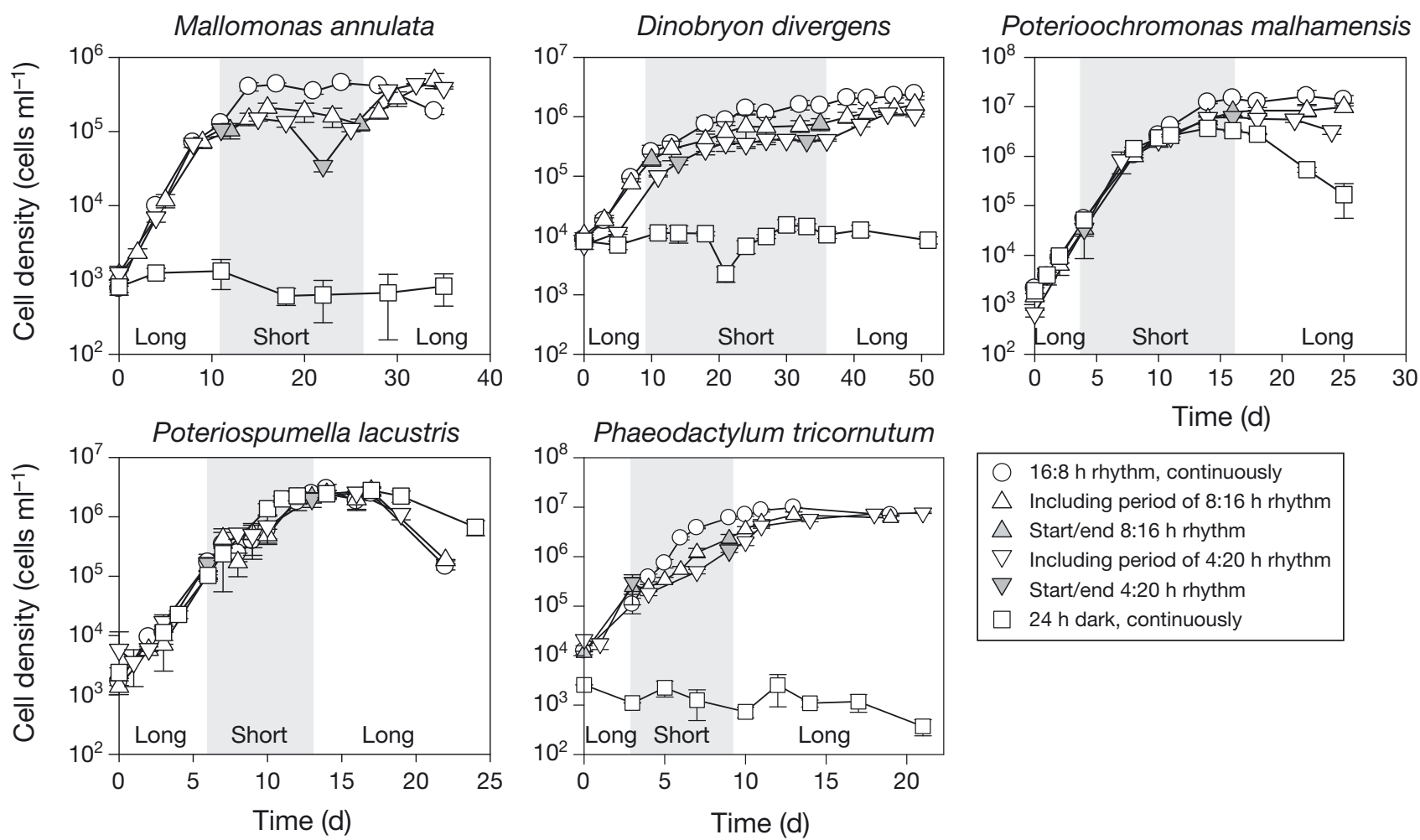

Fig 6. Growth of the investigated chrysophytes and Phaeodactylum tricornutum under different light regimes. Growth performance of cultures grown in a continuous $16 \mathrm{~h}$ light:8 h dark rhythm was compared to those partially grown in a $8 \mathrm{~h}$ light: 16 h dark rhythm, a $4 \mathrm{~h}$ light:20 h dark rhythm and in continuous darkness. Mallomonas annulata was grown under a $6 \mathrm{~h}$ light:18 $\mathrm{h}$ dark rhythm instead of $4 \mathrm{~h}$ light:20 h dark. All cultures, besides those kept continuously in the dark, were initially incubated under $16 \mathrm{~h}$ light:8 $\mathrm{h}$ dark conditions (long). Light intervals were then shortened for the cells that were incubated with periods of $4 \mathrm{~h}(6 \mathrm{~h})$ and $8 \mathrm{~h}$ light (short, grey shading), and afterward, the initial rhythm of $16 \mathrm{~h}$ light:8 h dark was re-applied (long). The grey shaded zone represents approximately the incubation period with shortened light intervals; the exact day of beginning and end of the incubation is indicated by filled symbols for each treatment. Each data point represents the mean of 3 samples; error bars represent standard deviations 
resources for survival have been accumulated in the organism before. The period of stationary phase was rather short in dark experiments with Poteriospumella lacustris and Poterioochromonas malhamensis growing with DOM. Regarding $P$. lacustris, this is in agreement with the finding that Spumella-like flagellates are typical r-strategists, i.e. they have high growth rates when food is available but little starvation tolerance if food is absent (Boenigk et al. 2006). Cells of P. malhamensis grown with DOM survived much longer in the light than under dark conditions, while there was no difference for P. lacustris (Fig. 6). In contrast to $P$. lacustris, $P$. malhamensis is able to compensate organic carbon limitation in the light by switching to a phototrophic maintenance metabolism, which allows the alga to survive but not to proliferate in the presence of light. In the dark, this mechanism does not work, and the onset of cell mortality appears much earlier in the stationary phase (see also Caron et al. 1990, Zhang \& Watanabe 2001). Altogether, our results show that $P$. lacustris is incapable of photoautotrophy, whereas $P$. malhamensis does not grow but sustains cell metabolism with the help of light-derived energy when organic carbon sources are limited.

Shortening of the light period resulted in lower growth rates of Dinobryon divergens (Fig. 6), and growth in the dark in the presence of particulate organic carbon was not observed (Fig. 2, Fig. S3). Oxygen evolution rates per biovolume were comparable to Poterioochromonas malhamensis (Fig. 5). Laboratory and field studies support our finding that Dinobryon is obligatorily light-dependent (Veen 1991, Caron et al. 1993, Watson et al. 2001, Watson \& McCauley 2010).

Although Mallomonas annulata has higher maximum oxygen evolution rates than Dinobryon divergens, both algae have rather low growth rates compared to Phaeodactylum tricornutum. For unicellular organisms with photoautotrophic abilities, growth in terms of increasing cell densities or increasing cell size is coupled to the acquisition of inorganic carbon and oxygen production. There is, however, no direct relation between oxygen production, $\mathrm{CO}_{2}$ consumption and growth. Oxygen is formed as a product of the photosynthetic light reaction, which provides energy and reduction equivalents for the complete formation of biomass by $\mathrm{CO}_{2}$ assimilation. In addition to the direct formation of photosynthesis products, there are various direct or indirect metabolic sinks for the reduction equivalents generated in the photosyn- thetic light reaction. In addition to the direct formation of photosynthesis products, there are various direct or indirect metabolic sinks for the reduction equivalents generated in the photosynthetic light reaction. For example, the production of more reduced cell compounds (e.g. accumulation of lipids or synthesis of complex secondary metabolites), the secretion of carbohydrates or the nitrogen assimilation starting from nitrate can confound the stoichiometry between oxygen production and increase of biomass. Hence, the differences in growth rates observed for organisms with similar photosynthetic capacities are not necessarily a consequence of different carbon-uptake abilities or strategies. Mixotrophy furthermore increases the independence between growth and oxygen production. Thus, the non-linear relations comparing oxygen evolution rates and growth rates of Poterioochromonas malhamenis, $D$. divergens, $M$. annulata and $P$. tricornutum to each other might be a result of different exploitation of organic carbon sources but might also be related to differences in the budgeting of reduction equivalents.

\section{SUMMARY}

The present study provides profound insights regarding the nutrition of diverse chrysophytes by comparing them under identical conditions. Covering the whole spectrum from photoautotrophic to chemoheterotrophic chrysophytes, we found large differences between the more chemoheterotrophically mixotrophic chrysophyte Poterioochromonas malhamensis and the more photoautotrophically mixotrophic strain Dinobryon divergens. We demonstrated that both mixotrophic algae act within a certain nutritional spectrum, so that a total shift from purely heterotrophic to purely autotrophic growth or vice versa cannot be induced by varying light availability or different carbon sources. We also showed that bacteria promote growth of $P$. malhamensis and $D$. divergens, but that $P$. malhamensis proliferates independently from light availability, whereas $D$. divergens is obligatory light-dependent. Mallomonas annulata shows greater oxygen evolution rates under lowlight conditions and, thus, different photosynthetic capacities than $D$. divergens. Individual growth responses regarding carbon and light availability were observed and, thus, a differential impact on the fitness of single chrysophytes in nature is anticipated. 
Acknowledgements. We thank J. Thielicke, K. Scholz and A. Förderer for help with the experiments and the Universität Konstanz BioImaging Center (BIC) for access to a confocal laser scanning microscope. We are very grateful to Prof. K.O. Rothhaupt for support and helpful discussions and to 3 anonymous reviewers for their helpful suggestions. This work was supported by the Universität Konstanz (Research Initiative 'Organismic interactions in aquatic ecosystems under changing conditions' to P.G.K.) and by projects FWF P21151 and BO 3245/3-1(DFG) to J.B.

\section{LITERATURE CITED}

Andersen RA, Van de Peer Y, Potter D, Sexton JP, Kawachi M, LaJeunesse T (1999) Phylogenetic analysis of the SSU rRNA from members of the Chrysophyceae. Protist 150: 71-84

Bhatti S, Colman B (2011) Evidence for the occurrence of photorespiration in synurophyte algae. Photosynth Res 109:251-256

Bird DF, Kalff J (1987) Algal phagotrophy: regulating factors and importance relative to photosynthesis in Dinobryon (Chrysophyceae). Limnol Oceanogr 32:277-284

Boenigk J, Arndt H (2002) Bacterivory by heterotrophic flagellates: community structure and feeding strategies. Antonie Van Leeuwenhoek 81:465-480

Boenigk J, Pfandl K, Hansen PJ (2006) Exploring strategies for nanoflagellates living in a 'wet desert'. Aquat Microb Ecol 44:71-83

> Caron DA, Porter KG, Sanders RW (1990) Carbon, nitrogen, and phosphorus budgets for the mixotrophic phytoflagellate Poterioochromonas malhamensis (Chrysophyceae) during bacterial ingestion. Limnol Oceanogr 35:433-443

Caron DA, Sanders RW, Lim EL, Marrase C and others (1993) Light-dependent phagotrophy in the fresh-water mixotrophic chrysophyte Dinobryon cylindricum. Microb Ecol 25:93-111

Chrzanowski TH, Simek K (1990) Prey-size selection by fresh-water flagellated protozoa. Limnol Oceanogr 35: 1429-1436

de Castro F, Gaedke U, Boenigk J (2009) Reverse evolution: driving forces behind the loss of acquired photosynthetic traits. PLoS ONE 29:e8465

> De Hoyos C, Aldasoro JJ, Toro M, Comin FA (1998) Specific composition and ecology of chrysophyte flagellates in Lake Sanabria (NW Spain). Hydrobiologia 369-370: 287-295

De Martino A, Meichenin A, Shi J, Pan KH, Bowler C (2007) Genetic and phenotypic characterization of Phaeodactylum tricornutum (Bacillariophyceae) accessions. J Phycol 43:992-1009

> Droop MR (1954) A note on the isolation of small marine algae and flagellates for pure cultures. J Mar Biol Assoc UK 33:511-514

> Findenig BM, Chatzinotas A, Boenigk J (2010) Taxonomic and ecological characterization of stomatocysts of Spumella-like flagellates (Chrysophyceae). J Phycol 46: 868-881

Gaedke U (1998) Functional and taxonomic properties of the phytoplankton community of large and deep Lake Constance: interannual variability and response to reoligotrophication (1979-1993). Adv Limnol 53:119-141

Guillard RRL (1975) Culture of phytoplankton for feeding marine invertebrates. In: Smith WL, Chanley MH (eds)
Culture of marine invertebrate animals. Plenum Press, New York, NY, p 29-60

Guillard RR, Lorenzen CJ (1972) Yellow-green algae with chlorophyllide C. J Phycol 8:10-14

Guillard RR, Ryther JH (1962) Studies of marine planktonic diatoms. 1. Cyclotella nana Hustedt, and Detonula confervacea (Cleve) Gran. Can J Microbiol 8:229-239

Hahn MW (2003) Isolation of strains belonging to the cosmopolitan Polynucleobacter necessarius cluster from freshwater habitats located in three climatic zones. Appl Environ Microbiol 69:5248-5254

> Hahn MW, Höfle MG (1998) Grazing pressure by a bacterivorous flagellate reverses the relative abundance of Comamonas acidovorans PX54 and Vibrio Strain CB5 in chemostat cocultures. Appl Environ Microbiol 64: 1910-1918

> Heinrich HC (1955) Der B-vitamin-Bedarf der Chrysophyceen "Ochromonas danica nom. provis. Pringsheim" und "Ochromonas malhamensis Pringsheim". Naturwissenschaften 42:418

Herth W, Zugenmaier P (1979) Lorica of Dinobryon. J Ultratruct Res 69:262-272

> Holen DA (1999) Effects of prey abundance and light intensity on the mixotrophic chrysophyte Poterioochromonas malhamensis from a mesotrophic lake. Freshw Biol 42: 445-455

> Hutner SH, Provasoli L, Filfus J (1953) Nutrition of some phagotrophic fresh-water chrysomonads. Ann NY Acad Sci 56:852-862

> Jeppesen E, Søndergaard M, Jensen JP, Havens KE and others (2005) Lake responses to reduced nutrient loading an analysis of contemporary long-term data from 35 case studies. Freshw Biol 50:1747-1771

Johnston AM, Raven JA (1996) Inorganic carbon accumulation by the marine diatom Phaeodactylum tricornutum. Eur J Phycol 31:285-290

Jones RI, Rees S (1994) Influence of temperature and light on particle ingestion by the fresh-water phytoflagellate Dinobryon. Arch Hydrobiol 132:203-211

Jordan RW, Iwataki M (2012) Chrysophyceae and Synurophyceae. In: Encyclopedia of life sciences. John Wiley \& Sons, New York, NY, doi:10.1002/9780470015902.a002 3690

Kamjunke N, Henrichs T, Gaedke U (2007) Phosphorus gain by bacterivory promotes the mixotrophic flagellate Dinobryon spp. during re-oligotrophication. J Plankton Res 29:39-46

> Kamp A, de Beer D, Nitsch JL, Lavik G, Stief P (2011) Diatoms respire nitrate to survive dark and anoxic conditions. Proc Natl Acad Sci USA 108:5649-5654

Kim JH, Lee KL, Kim HS (2009) Effect of nutrients and light intensity on growth of Mallomonas caudata (Synurophyceae). Nord J Bot 27:516-522

Kristiansen J, Preisig HR (2007) Süßwasserflora von Mitteleuropa, Vol 1-2. In: Preisig HR (ed) Chrysophyte and haptophyte algae. Spektrum Akademischen Verlag, Berlin

> Lee KL, Kim JH, Yoon HS, Kim HS (2012) Growth characteristics of two bloom-forming synurophytes (Mallomonas elongata and Synura petersenii) at different nitrate and phosphate concentrations. Nord J Bot 30:104-108

Lehman JT (1976) Ecological and nutritional studies on Dinobryon Ehrenb.: seasonal periodicity and phosphate toxicity problem. Limnol Oceanogr 21:646-658

Maberly SC, Ball LA, Raven JA, Sültemeyer D (2009) Inor- 
ganic carbon acquisition by chrysophytes. J Phycol 45: 1052-1061

- Massana R (2011) Eukaryotic picoplankton in surface oceans. Annu Rev Microbiol 65:91-110

Matsuda Y, Nakajima K, Tachibana M (2011) Recent progresses on the genetic basis of the regulation of $\mathrm{CO}_{2}$ acquisition systems in response to $\mathrm{CO}_{2}$ concentration. Photosynth Res 109:191-203

Moser M, Weisse T (2011a) Combined stress effect of $\mathrm{pH}$ and temperature narrows the niche width of flagellates in acid mining lakes. J Plankton Res 33:1023-1032

Moser M, Weisse T (2011b) The outcome of competition between the two chrysomonads Ochromonas sp. and Poterioochromonas malhamensis depends on $\mathrm{pH}$. Eur J Protistol 47:79-85

Müller AM, Wilhelm C (1997) Light adaptation of the phytoplankton diatom Phaeodactylum tricornutum under conditions of natural light climate. Int Rev Hydrobiol 82: 315-328

> Myers J, Graham JR (1956) The role of photosynthesis in the physiology of Ochromonas. J Cell Comp Physiol 47: 397-414

> Patel BN, Merrett MJ (1986) Inorganic-carbon uptake by the marine diatom Phaeodactylum tricornutum. Planta 169: 222-227

Porter KG (1988) Phagotrophic phytoflagellates in microbial food webs. Hydrobiologia 159:89-97

Pringsheim EG (1952) On the nutrition of Ochromonas $Q \mathrm{~J}$ Microsc Sci 93:71-96

Raven JA, Holen DA, Boraas ME (1995) Development, physiology and nutrition. In: Sandgren CD, Smol JP, Kristiansen J (eds) Chrysophyte algae: ecology, phylogeny, and development. Cambridge University Press, Cambridge, p 93-119

Reazin GH (1956) The metabolism of glucose by the alga Ochromonas malhamensis. Plant Physiol 31:299-303

Rothhaupt KO (1996a) Laboratory experiments with a mixotrophic chrysophyte and obligately phagotrophic and phototrophic competitors. Ecology 77:716-724

Rothhaupt KO (1996b) Utilization of substitutable carbon and phosphorus sources by the mixotrophic chrysophyte Ochromonas sp. Ecology 77:706-715

Rottberger J, Gruber A, Kroth PG (2013) Analysing size variation during light-starvation response of nutritionally diverse chrysophytes with a Coulter counter. Algol Stud 141:37-51

Sanders RW, Porter KG (1988) Phagotrophic phytoflagellates. Adv Microb Ecol 10:167-192

Sanders RW, Porter KG, Caron DA (1990) Relationship between phototrophy and phagotrophy in the mixotrophic chrysophyte Poterioochromonas malhamensis. Microb Ecol 19:97-109

Editorial responsibility: Karel Simek, Ceske Budejovice, Czech Republic
Sandgren CD (1988) The ecology of chrysophyte flagellates: their growth and perennation strategies as freshwater phytoplankton. In: Sandgren CD (ed) Growth and reproductive strategies of freshwater phytoplankton. Cambridge University Press, Cambridge, p 9-104

Schlösser UG (1994) SAG - Sammlung von Algenkulturen at the University of Göttingen; catalogue of strains 1994. Bot Acta 107:113-186

Scott CE, Saros JE, Williamson CE, Salm CR, Peters SC, Mitchell DL (2009) Effects of nutrients and dissolved organic matter on the response of phytoplankton to ultraviolet radiation: experimental comparison in spring versus summer. Hydrobiologia 619:155-166

Sherr BF, Sherr EB, Fallon RD (1987) Use of monodispersed, fluorescently labeled bacteria to estimate in situ protozoan bacterivory. Appl Environ Microbiol 53:958-965

> Thingstad TF, Havskum H, Garde K, Riemann B (1996) On the strategy of 'eating your competitor': a mathematical analysis of algal mixotrophy. Ecology 77:2108-2118

> Unrein F, Massana R, Alonso-Saez L, Gasol JM (2007) Significant year-round effect of small mixotrophic flagellates on bacterioplankton in an oligotrophic coastal system. Limnol Oceanogr 52:456-469

Valenzuela J, Mazurie A, Carlson R, Gerlach R, Cooksey K, Peyton B, Fields M (2012) Potential role of multiple carbon fixation pathways during lipid accumulation in Phaeodactylum tricornutum. Biotechnol Biofuels 5:40

> van Donk E, Veen A, Ringelberg J (1988) Natural community bioassays to determine the abiotic factors that control phytoplankton growth and succession. Freshw Biol 20:199-210

> Van Donk E, Cerbin S, Wilken S, Helmsing NR, Ptacnik R, Verschoor AM (2009) The effect of a mixotrophic chrysophyte on toxic and colony-forming cyanobacteria. Freshw Biol 54:1843-1855

Veen A (1991) Ecophysiological studies on the phagotrophic phytoflagellate Dinobryon divergens Imhof. PhD dissertation, University of Amsterdam

Watson SB, McCauley E (2010) Light and bacteria: substitutable energy sources for chrysophyte blooms? Nova Hedwigia Beih 136:213-230

> Watson SB, Satchwill T, Dixon E, McCauley E (2001) Underice blooms and source-water odour in a nutrient-poor reservoir: biological, ecological and applied perspectives. Freshw Biol 46:1553-1567

> Wilken S, Huisman J, Naus-Wiezer S, Van Donk E (2013) Mixotrophic organisms become more heterotrophic with rising temperature. Ecol Lett 16:225-233

Zhang XM, Watanabe MM (2001) Grazing and growth of the mixotrophic chrysomonad Poterioochromonas malhamensis (Chrysophyceae) feeding on algae. J Phycol 37:738-743

Submitted: February 25, 2013; Accepted: September 16, 2013 Proofs received from author(s): November 15, 2013 